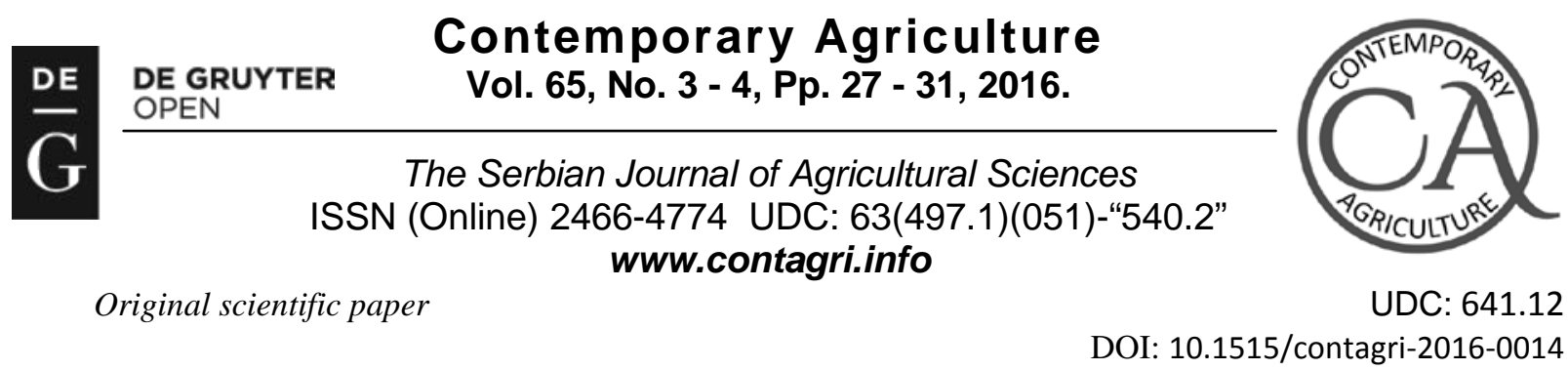

\title{
EFFECT OF PRODUCTION SYSTEMS ON QUALITY AND CHEMICAL COMPOSITION OF TABLE EGGS*
}

\author{
Lidija PERIĆ ${ }^{1}$, Mirjana ĐUKIĆ STOJČIĆ ${ }^{1}$, Siniša BJEDOV ${ }^{1}$
}

\begin{abstract}
Summary: Production system is one of the most important factors which have an effect on egg quality. In recent years consumers have paid more attention to the housing system in which eggs are produced with a significant increase of their interest in organic and functional food. Some consumers perceive omega-3 enriched eggs and free range eggs as beneficial for their health. Therefore, the aim of this work was to determine the chemical composition and the internal and external quality of eggs produced in conventional cages, free range systems and of omega-3 enriched eggs. Samples of 30 eggs from three different production systems were taken from the market. For eggs from each system the internal and external egg quality traits were examined as well as the protein and fat content.The results showed lower fat content in eggs from cages $(P<0.05)$.Free range and omega-3 eggs had higher content of protein in egg white compared to the conventional ones $(P<0.05)$. Production system significantly influenced the shell breaking strength, Haugh units and yolk color. The shell breaking force was significantly higher in free range eggs $(P<0.05)$. The highest value of Haugh units was found in free range eggs and the lowest in omega-3 enriched eggs. The results of this work confirmed that there are differences in quality and the chemical composition of eggs from different production systems.
\end{abstract}

Key words: eggs, quality, free range, omega- 3, conventional cages

\section{INTRODUCTION}

One of the important factors which have an effect on egg quality traits is the production system.As a result of improvements in the management, disease control, nutrition, genetics and technology, egg quality and composition have undoubtedly changed (Sekeroglu et al., 2010). This is one of the reasons why consumers started to pay attention to the housing system in which eggs are produced with a significantly increased interest in so-called "healthy food". Many consumers consider that free range and organic eggs are healthier compared to the eggs which are produced in cages (Rodić et al., 2010a). However, there is no evidence that the cholesterol content of eggs is lower in organic than in regular eggs, although the fatty acid (FA) profile may be favorable (Samman et al., 2009; Terčić et al., 2012).The offer of organic and free range eggs is still very poor in Serbia. According to Rodić et al. (2010b) consumers in Serbia would choose eggs from the free range system (51.2\%) or organic production (26.4\%) if there was an offer on the market.

Besides organic food, in recent years there has been an increasing demand for functional food. People have become aware of the strong connection between food and their health, especially in developed European countries and US (Perić et al., 2011). In this sense, they started to show more interest in the quality of poultry meat and eggs and the demand for enriched poultry meat and eggs is rising. Although claims made in the popular press extol the virtue of one housing system over another to enhance egg vitamin and n-3 fatty acid content, few controlled studies have been undertaken to justify such assertions (Holt et al., 2011). This underscores the need for a concerted research effort to compare the nutritional composition of eggs from hens raised under different production conditions.

Some consumers perceive food as a possibility to realize certain benefits because they are additionally enriched with substances beneficial for their health (Grashorn, 2005; Weberke, 2005). This is reflected in the appearance of

\footnotetext{
${ }^{1}$ Lidija Perić, PhD, Full Professor, Mirjana Đukić Stojčić, PhD, Associate Professor, Siniša Bjedov, PhD, Research Assistant, University of Novi Sad, Faculty of Agriculture, Trg Dositeja Obradovića 8, 21000 Novi Sad, Srbija

*This research is a part of project TR31033 supporting by Ministry of Science and Technological Development, Republic of Serbia

•Corresponding author: e-mail: lidija.peric@stocarstvo.edu.rs, Tel.:+381214853385
} 
the omega-3 enriched eggs in Serbian supermarkets. However, the quality of enriched eggs and free range eggs which can be found on the market is still insufficiently tested.

Therefore, the aim of this work was to determine the chemical composition and the internal and external quality of eggs produced in conventional cages, free range systems and of omega-3 enriched eggs that can be found on the Serbian market.

\section{MATERIAL AND METHODS}

Eggs sampling was carried out in one of the biggest supermarket chains. Samples of 30 eggs were taken from three different production systems: conventional cages, free range and omega-3 enriched eggs from birds kept in cages. All eggs were put on the market at the same time and all eggs were B weight class. For eggs from each system the internal and external egg quality traits were examined. Egg weight was measured on a precision scale. Shell color was assessed by points from 1 (pale) to 5 (dark brown). Shell cleanness was assessed by points on a scale from 0 (clean) to 3 (very dirty). Shell breaking force was determined by Egg Force Reader (Orka Food Technology Ltd, Israel). Yolk color was determined using the Roche yolk color fan. Albumen height was measured with a tripod micrometer. On the basis of egg mass $(\mathrm{M})$ and albumen height $(\mathrm{H})$, Haugh units were calculated according to formula $\mathrm{HU}=100 \log (\mathrm{H}+7.57-1,7 \mathrm{M} 0.37)$.

Protein content in the eggs was determined by the Kjeldahl method and fat content was determined using the Soxlet method. Statistical analyses were done in STATISTICA 12 (Stat Soft, 2015) using ANOVA with Duncan's post-hoc test.

\section{RESULTS}

Significant differences in chemical composition were established between the eggs produced in different production systems (table 1). Free range and omega-3 eggs had significantly higher content of protein in egg white compared to conventional ones $(\mathrm{P}<0.05)$. The same situation was noticed in egg yolk but the difference was not significant. Interestingly, the highest level of fat was found in free range eggs and the difference was significant compared to cage eggs $(\mathrm{P}<0.05)$ but not to omega-3 eggs.

Table 1. Chemical composition of eggs from different production systems (mean \pm SD)

\begin{tabular}{|c|c|c|c|}
\hline \multirow{2}{*}{ Nutrient, \% } & \multicolumn{3}{|c|}{ Production system } \\
\cline { 2 - 4 } & Conventional cages & Omega-3 enriched & Free range \\
\hline \multicolumn{3}{|c|}{ Egg white } \\
\hline Crude proteins & $8.32 \pm 0.62^{\mathrm{b}}$ & $9.22 \pm 1.12^{\mathrm{a}}$ & $0.34 \pm 0.34$ \\
\hline Crude fat & $0.16 \pm 0.04$ & $0.32 \pm 0.17$ & $15.65 \pm 1.20$ \\
\hline \multicolumn{3}{|c|}{ Egg yolk } \\
\hline Crude proteins & $15.20 \pm 0.36$ & $16.07 \pm 0.93$ & $26.13 \pm 1.31^{\mathrm{a}}$ \\
\hline
\end{tabular}

${ }^{\mathrm{a}-\mathrm{b}}$ Values in the same row without common superscript are significantly different $(\mathrm{P}<0.05)$

Housing system significantly affected the inner and outer traits of the egg quality (table 2).

Table 2. Quality traits of eggs from different production systems (mean \pm SD)

\begin{tabular}{|c|c|c|c|}
\hline \multirow{2}{*}{ Egg quality traits } & \multicolumn{3}{|c|}{ Production system } \\
\cline { 2 - 4 } & Conventional cages & Omega-3 enriched & Free range \\
\hline Egg weight, g & $55.36 \pm 2.31^{\mathrm{c}}$ & $59.27 \pm 2.61^{\mathrm{a}}$ & $56.80 \pm 1.62^{\mathrm{b}}$ \\
\hline Shell color, points & $4.06 \pm 0.94$ & $3.82 \pm 1.00$ & $1.30 \pm 0.65$ \\
\hline Shell cleanness, points & $1.20 \pm 0.40$ & $1.27 \pm 0.45$ & $77.76 \pm 2.12$ \\
\hline Shape index & $75.83 \pm 3.04$ & $74.48 \pm 2.70$ & $4.46 \pm 1.36^{\mathrm{a}}$ \\
\hline Shell breaking force, $\mathrm{kg}$ & $3.65 \pm 1.54^{\mathrm{b}}$ & $3.48 \pm 1.19^{\mathrm{b}}$ & \\
\hline
\end{tabular}




\begin{tabular}{|c|c|c|c|}
\hline Shell thickness, $0.01 \mathrm{~mm}$ & $38.33 \pm 4.09$ & $38.31 \pm 3.55$ & $37.86 \pm 2.28$ \\
\hline Shell weight, g & $6.26 \pm 0.69^{\mathrm{b}}$ & $7.13 \pm 0.87^{\mathrm{a}}$ & $6.63 \pm 0.55^{\mathrm{b}}$ \\
\hline Albumen height, mm & $4.51 \pm 1.09^{\mathrm{b}}$ & $2.81 \pm 1.04^{\mathrm{c}}$ & $5.82 \pm 1.49^{\mathrm{a}}$ \\
\hline Haugh units & $64.70 \pm 11.31^{\mathrm{b}}$ & $38.90 \pm 17.80^{\mathrm{c}}$ & $74.82 \pm 12.71^{\mathrm{a}}$ \\
\hline Yolk color (Roche) & $13.16 \pm 0.59^{\mathrm{b}}$ & $14.00 \pm 0.84^{\mathrm{a}}$ & $11.10 \pm 0.48^{\mathrm{c}}$ \\
\hline
\end{tabular}

Values in the same row without common superscript are significantly different ${ }^{\mathrm{a}-\mathrm{c}}(\mathrm{P}<0.05)$

Egg weight was significantly different between groups, but these results should be considered with caution because the eggs were taken from the market and were classified as B class (55-60g). It is questionable if egg weight, as well as the shell cleanness, should be compared in market studies.

There were no significant differences between groups in shape index and shell thickness, but the shell breaking force was significantly higher in free range eggs $(\mathrm{P}<0.05)$. That indicates that free range birds might have an access to additional Ca sources on the range. Interestingly, shell weight was significantly higher in omega-3 enriched eggs, despite the lowest shell breaking force.

The biggest difference was found in albumen quality between the eggs from different production systems. The highest value of Haugh units was found in free range eggs and the lowest in omega-3 enriched eggs. Since this research is a typical market study it is questionable for how long the eggs were stored at the producer's cold storage before they entered the market. Unfortunately this situation is something that consumers in Serbia are faced with.

A significant effect of the production system on yolk color was noticed. The eggs from free range had the palest yolks which is completely opposite to consumers expectations. Considering that egg producers can add the synthetic pigments in feed for layers and achieve the desirable yolk color, this quality trait becomes less important in the evaluation of egg quality.

\section{DISCUSSION}

There is a large degree of variability in the research findings on the effects of various housing systems on egg composition and quality. The results of this research showed that production system significantly affects the chemical composition of the egg. The same result was reported by Perić et al. (2015a; 2015b) who stated that eggs from organic production had higher fat content in yolks compared to eggs from conventional cages. On the contrary, Minelli et al. (2007) did not find any difference in the fat content in yolk between free range and conventional eggs. It is important to emphasize that most of the research on nutritional composition of organic eggs has been directed at the fatty acid composition and the level of cholesterol rather than fat content (Samman et al., 2009).

A significant effect of production system was established on shell quality - shell breaking force and shell weight. Most of the authors agree that production system had a significant influence on shell characteristics. For example, Mertens et al. (2006) detected the highest percentage of cracked eggs at the point of lay in conventional and furnished cages, with lower levels in aviary and free-range production. Similarly, Perić et al. (2015b) established that free range eggs had better shell strength compared to the eggs from conventional cages. Hidalgo et al. (2008) reported the greatest percentage of shell and shell strength in conventional cage eggs versus all other housing systems monitored (free-range, barn, and organic). In a comparison study of conventional cage and free-range production, shell quality decreased in the caged hens with hen age but remained constant or increased in the freerange eggs (Van Den Brand et al., 2004). Pavlovski et al. (2001) confirmed that housing system affects the shell quality. They detected thicker shells in barn eggs compared to free range eggs. Sekeroglu et al. (2010) found no difference in egg shell thickness between free range and conventional eggs. Generally, the research findings are inconsistent and do not provide a clear indication which production system provides eggs with the best shell quality.

When it comes to yolk color many inconsistencies can be found in the literature. Most of the authors agree that yolk color is significantly affected by housing systems. Van Den Brand et al. (2004) compared egg quality in hens housed in individual cages and hens housed on range with males and established that yolk color was darker in the free-range eggs. The same finding was reported by Holt et al. (2011). On the contrary, Hidalgo et al. (2008), Terčić et al. (2012) and Perić et al. (2015b) found that yolks from organic eggs were paler compared to conventional eggs. They all agree that using feed with synthetic pigments results in higher yolk yellowness. In contrast to both groups of results, Sekeroglu et al. (2010) found no statistical difference in yolk color between the free range and conventional eggs.

A significant effect of housing system was noticed on the internal quality of eggs especially on albumen quality. Similar results are reported by other authors. In the research of Perić et al. (2015b) Haugh units (HU) were 
significantly lower in organic and free range eggs compared to the eggs from cages. Patterson et al. (2001) and Đukić Stojčić et al. (2015) also observed lower HU values in organic eggs vs. conventional cage. Terčić et al. (2012) found lower value of Haugh units in organic eggs, but the difference was not significant. The same result was reported by Sekeroglu et al. (2010) between the free range and conventional cages. The causes of lower HU values in organic and free range eggs have to be further investigated since albumen quality is determined not only by egg freshness but also by hen age, genotype and dietary ingredients (Hidalgo et al.,2008; Silversides and Scott, 2001).

\section{CONCLUSION}

The results of this work confirmed the differences in quality and the chemical composition of eggs from different production systems. The difference was the most prominent in fat content in the egg yolk, which was significantly lower in conventional eggs. The eggs from free range production showed better shell quality compared to the other two groups. Production system significantly influenced the albumen quality and the yolk color. Omega-3 eggs had the darkest yolks, but the lowest HU values. Generally, direct comparisons among the different types of production system are difficult because many variables differ between systems (strain of laying hens, age, feeding). However, so called "market research" is still needed to find out more about the quality of eggs which are offered to the consumers.

\section{REFERENCES}

ĐUKIĆ STOJČIĆ, M. PERIĆ, L., MILOŠEVIĆ, N., BJEDOV, S.: The eggs quality from organic and conventional production. Book of Abstracts, IV International Symposium and XX Scientific professional Conference of Agronomists of Republic of Srpska, March 2nd - 6th, 2015 Bijeljina, Bosnia and Herzegovina, 195, 2015.

GRASHORN M.A.: Enrichment of eggs and poultry meat with biologically active substances by feed modifications and effects on the final quality of the product. Polish Journal of Food and Nutritional Science, 1, 15-20, 2005.

HIDALGO, A., ROSSI, M., CLERIC, F., RATTI, S.: A market study on the quality characteristics of eggs from different housing systems. Food Chemistry, 106, 1031-1038, 2008.

HOLT, P.S., DAVIES, R.H., DEWULF, J., GAST, R.K., HUWE, J.K., JONES, D.R., WALTAN, D., WILLIAN, K.R.: Theimpact of different housing systems on egg safety and quality. Poultry Science, 90:251-262, 2011.

MERTENS, K., BAMELIS, F., KEMPS, B., KAMERS, B., VERHOELST, E. DE KETELAERE, B., BAIN, M., DECUYPERE, E., DE BAERDEMAEKER.J.: Monitoring of eggshell breakage and eggshell strength in different production chains of consumption eggs. Poultry Science, 85:1670-1677,2006.

MINELLI, G., SIRRI, F., FOLEGATTI, E., MELUZZI, A., FRANCHINI, A.: Egg quality traits of laying hens reared in organic and conventional systems. Italian Journal of Animal Science, 6: 728-730, 2007.

PATTERSON, P.H., KOELKEBECK, K.W., BELL, D.D., CAREY ,J.B., ANDERSON, K.E., DARRE, MJ.:Egg marketing in national supermarkets: specialty eggs - Part 2. Poultry Science, 80, 390-395, 2001.

PAVLOVSKI, Z., HOPIC, S., LUKIC, M.: Housing systems for layers and egg quality. Biotechnology in Animal Husbandry, 17, 197-201, 2001.

PERIĆ, L., RODIĆ, V., MILOŠEVIĆ, N.: Production of poultry meat and eggs as functional food. Proceedings of the 3rd INTERNATIONAL CONGRESS “New Perspectives and Challenges of Sustainable Livestock Production”. Belgrade, Republic of Serbia 5 - 7th October 2011. pp. 511-520, 2011.

PERIĆ, L., ĐUKIĆ STOJČIĆ, M. MILOŠEVIĆ, N., BJEDOV, S. Effect of organic production on chemical composition of eggs. Book of Abstracts, IV International Symposium and XX Scientific professional Conference of Agronomists of Republic of Srpska, March 2nd - 6th, 2015 Bijeljina, Bosnia and Herzegovina, 338, 2015 a.

PERIĆ L., ĐUKIĆ STOJČIĆ M. MILOŠEVIĆ N., BJEDOV S.: Effects of different housing systems on quality of table eggs. Proceedings of the 4th International Congress New Perspectives and Challenges of Sustainable Livestock Production, October 7 9, 2015, pp. 558-564, 2015b.

RODIĆ, V., PERIĆ, L., PAVlOVSKI, Z., VLAHOVIĆ, B.: Consumers'perception and attitudes towards table eggs from different housing systems. CD-ROM Proceedings of the XIIIth European Poultry Conference, Tours, France, 2010a.

RODIĆ, V., PERIĆ, L., PAVLOVSKI, Z., MILOŠEVIĆ, N.: Competitiveness of table eggs from non-cage housing systems. Biotechnology in Animal Husbandry 26, 1-2:117-128, 2010b.

SAMMAN, S., KUNG, F.P., CARTER, L.M., FOSTER, M.J., AHMAD, Z.I, PHUYAL, J.L. PETOCZ, P.: Fatty acid composition of certified organic, conventional and omega-3 eggs. Food Chemistry 116: 911-914, 2009.

SEKEROGLU, A., SARICA, M., DEMIR, E., UlUTAS, Z., TILKI, M., SAATCI, M., OMED, H.: Effects of different housing systems on some performance traits and egg qualities of laying hens. Journal of Animal and Veterinary Advances 9, 12:1379-1744, 2010.

SILVERSIDES, F.G., SCOTT, T.A.: Effect of storage and layer age on quality of eggs from two lines of hens. Poultry Science, 80:1240-1245,2001. 
TERČIĆ, D., ŽLENDER, B., HOLCMAN, A.: External, internal and sensory qualities of table eggs as influenced by two different production systems. Agroznanje, 13, 4:555-562, 2012.

VAN DEN BRAND, H., PARMENTIER, H. K., KEMP, B.: Effects of housing system (outdoor vs cages) and age of laying hens on egg characteristics. British Poultry Science, 45:745-752, 2004.

WEBERKE, V.: Consumer acceptance of functional foods: sociodemographic, cognitive and attitudinal 2004. determinants. Food Quality and Preference, 16, 1: 45-57, 2005.

\section{EFEKAT RAZLIČITIH SISTEMA PROIZVODNJE NA KVALITET I HEMIJSKI SASTAV KONZUMNIH JAJA}

Izvod: Sistem proizvodnje je jedan od najbitnijih faktora koji utiču na kvalitet konzumnih jaja. Poslednjih godina potrošači sve više pažnje obraćaju na sisteme držanja kokoši nosilja sa posebnim akcentom na organsku proizvodnju i funkcionalnu hranu. Neki potrošači smatraju da su omega-3 obogaćena jaja i jaja sa ispusta korisna za njihovo zdravlje. Zbog toga je cilj ovog rada da utvrdi kvalitet i hemijski sastav jaja iz konvencionalnih kaveza, jaja sa ispusta i omega-3 obogaćenih jaja. Uzorak od 30 jaja iz sva tri navedena proizvodna sistema je uzet sa tržišta. Kod svih jaja određen je unutrašnjih i spoljašnji kvalitet, kao i sadržaj masti i proteina. Rezultati su pokazali značajno manji sadržaj masti u jajima iz kaveza $(P<0,05)$. Jaja sa ispusta i omega-3 obogaćena jaja imala su značajno viši sadržaj proteina u belancetu u odnosu na jaja iz kaveza $(P<0,05)$. Sistem držanja je imao značajan uticaj i na kvalitet ljuske, Hogove jedinice i boju žumanca. Sila loma ljuske je bila značajno veća $(\mathbf{P}<0,05)$ kod jaja sa ispusta. Najbolji kvalitet belanca i najviše vrednosti Hogovih jedinica imala su jaja sa ispusta, a najlošiji kvalitet belanca utvrđen je kod omega-3 obogaćenih jaja. Rezultati ovog rada su potvrdili da postoje značajne razlike u kvalitetu i hemijskom sastavu jaja iz različitih sistema držanja.

Ključne reči: jaja, kvalitet, ispust, omega-3, konvencionalni kavez

Received / Primljen: 16.10.2016.

Accepted / Prihvaćen: 16.11.2016. 